\title{
LITERASI BUDAYA: MEMAHAMI LOKALITAS PEREMPUAN BALI DARI KUMPULAN CERPEN SAGRA
}

\section{CULTURAL LITERACY: COMPREHEND BALINESE WOMAN LOCALITY IN SHORT STORY COLLECTION OF SAGRA}

\author{
Yessy Hermawati, N. Yeffa Afnita Apriliyani \\ Prodi Pendidikan Bahasa dan Sastra Indonesia \\ FKIP, Universitas Islam Nusantara, Bandung \\ Pos-el: yessy.hermawati@gmail.com, yefaafnita@gmail.com
}

*) Naskah diterima: 8 April 2020; direvisi: 8 April 2020; disetujui: 6 Oktober 2020

\begin{abstract}
Abstrak
Salah satu cara memahami budaya yaitu melalui kegiatan literasi. Kegiatan ini dapat dilakukan dengan cara membaca dan memaknai teks sastra. Tulisan ini membahas literasi budaya melalui pembacaan teks sastra yaitu cerpen tentang lokalitas perempuan. Lokalitas dalam hal ini merujuk pada unsur-unsur budaya baik budaya tradisi maupun budaya populer yang membentuk kehidupan perempuan. Adapun teks cerpen yang akan dibahas yaitu kumpulan cerpen karya Oka Rusmini (2017) yang berjudul Sagra. Teori yang digunakan dalam penelaahan teks cerpen yaitu teori literasi, feminitas normatif dan lokalitas. Metode yang digunakan yaitu metode kajian pustaka dengan cara membaca, menandai dan menganalisis teks-teks dalam cerpen yang menunjukan lokalitas perempuan yang berlatar budaya Bali. Pembahasan makalah ini menunjukan bahwa perempuan Bali dengan latar kehidupan budaya yang masih menganut sistem kasta membentuk identitas dan lokalitas perempuan yang khas dibandingkan latar budaya lainnya di Indonesia. Pengaruh Agama Hindu, adat dan kuasa patriaki masih kental memengaruhi lokalitas perempuan Bali dalam teks cerpen Sagra.
\end{abstract}

Kata kunci: literasi budaya, lokalitas, perempuan, cerpen, Oka Rusmini

\begin{abstract}
A cultural understanding is needed to understand the traces and development of a culture. One method to understand that is by doing cultural literacy activity. This activity can be done by reading and interpreting literary texts. This paper explores cultural literacy activity by short story reading about women locality. In this case the locality refers to tradition or popular cultural values that build the women's lives. The short story used in the discussion is a short story collection book written by Oka Rusmini (2017) named Sagra. Theories used to analyze the texts are literacy, normative femininity, and locality theories. Literature review is used as the method by reading, marking, and analyzing the cultural and women locality in Bali that can be found in the text. The discussion in this paper shows that Balinese women locality within caste system is influenced by religion, custom, and the power of patriarch.
\end{abstract}

Keywords: cultural literacy, locality, women, short story, Oka Rusmini 


\section{PENDAHULUAN}

Kehidupan perempuan sangat kuat dipengaruhi budaya yang melingkupi hidupnya.Perempuan juga memiliki peran dalam menjalankan dan menjaga budaya tersebut. Namun, dalam realitasnya tak selamanya peran dan nilai budaya tersebut memberikan kehidupan yang adil bagi mereka. Sistem patriarki yang sebagian besar memengaruhi suatu budaya membuat perempuan mengalami keterbatasan dan diskriminasi, baik pada diri individu maupun secara sosial. Hal ini sering diresepsi oleh perempuan sebagai sesuatu yang wajar karena secara turun temurun disampaikan antar generasi sehingga dianggap sebagai suatu yang harus diterima, dijaga, dan dipatuhi.

Dalam masyarakat Bali, perempuan memiliki peran besar untuk menjaga keberlangsungan budaya yang sangat terkait dengan agama dan adat istiadat. Hal ini sejalan dengan yang diungkapkan oleh Mantra (2011) bahwa peran perempuan Bali sangatlah besar dalam menjalankan roda keagamaan dan memelihara adat-istiadat Bali dari level keluarga hingga tingkat masyarakat yang lebih luas. Namun, di balik peran yang besar tersebut, perempuan Bali juga mendapat beban berupa aturan yang berat dalam menjalani hidupnya yang didasarkan pada sistem kasta, agama, dan adat istiadat.

Masalah-masalah yang terjadi pada kehidupan perempuan menjadi topik yang menarik untuk diceritakan kembali. Berbagai media mencoba untuk merepresentasikan kehidupan perempuan, salah satu media tersebut adalah karya sastra. Karya sastradalam hal ini berupa novel, cerpen, puisi, drama, tak luput dalam merepresentasikan berbagai masalah budaya terutama yang terkait tentang kehidupan perempuan.

Karya sastra menurut Windiyarti (2008:286-294) merupakan produk budaya yang diyakini mengomunikasikan suatu pengalaman batin manusia berupa permasalahan kemanusiaan yang lahir dari pengarang sebagai pencipta, sekaligus sebagai kelompok masyarakat setempat. Abdulfatah, Widodo, dan Rohmadi (2018:12--23) juga menyampaikan karya sastra sebagai sarana untuk menyampaikan pesan tentang kebenaran. Selain itu, sastra sebagai salah satu dari berbagai bentuk representasi budaya, di dalamnya juga menggambarkan relasi dan rutinitas gender (Astuti dan Umiati, 2018:98--115). Oleh karena itu, representasi kehidupan perempuan dalam karya sastra memiliki kekuatan untuk menjelaskan sebuah realitas dalam budaya tertentu.

Karya sastra sebagai produk budaya yang ditulis oleh pelaku budaya dapat membantu pembacanya memahami lebih dalam tentang suatu budaya. Dengan pembacaan terhadap karya sastra yang merepresentasikan kehidupan perempuan, dapat dipahami pengetahuan dan pengalaman tentang hidup perempuan. Setelah itu, kita juga dapat melihat dan membaca permasalahan yang terjadi di dalamnnya. Untuk memahaminya diperlukan pembacaan terhadap teks-teks sastra secara mendalam dan kritis. Hal ini merupakan salah satu bentuk literasi budaya.

Literasi selama ini hanya dipahami sebagai kemampuan membaca dan menulis. Tetapi, literasi memiliki pemahaman yang lebih kompleks dan dalam, salah satunya untuk memahami sesuatu sebagai bekal menyelesaikan suatu permasalahan. Hirsch (1983) mengembangkan istilah literasi budaya dan menurutnya seseorang dianggap memahami tentang literasi budaya ketika ia tahu apa yang seharusnya diketahui oleh suatu anggota dan lingkunganbudaya tertentu, baik itu suatu hal yang disampaikan secara langsung ataupun tidak langsung. Saepudin,dkk (2018) menyampaikan 
pengembangan literasi budaya diperlukan sebagai dasar untuk pengenalan budaya dan proses pembelajaran budaya terhadap masyarakat. Kemendikbud (2017) juga menyampaikan literasi budaya sebagai kemampuan dalam memahami dan bersikap terhadap kebudayaan Indonesia sebagai identitas bangsa. Dalam hal ini literasi budaya berarti cara memahami suatu budaya agar kita mampu menyikapi budaya tersebut sebagai pengetahuan dan pengalaman. Oleh karena itu, literasi budaya juga dapat dipahami melalui pembacaan teks karya sastra yang merepresentasikan pengalaman budaya penulisnya.

Salah satu penulis perempuan Indonesia yang konsisten menyajikan cerita tentang perempuan dalam konteks budaya dan lokalitas yaitu Oka Rusmini. Menurut Noor (2015) yang juga salah seorang sastrawan Indonesia dalam opininya mengatakan bahwa Oka Rusmini merupakan salah satu sastrawan berlatar belakang budaya Bali yang seolah "Penuh Kesadaran Estetis" menjadikan Budaya Bali sebagai identitas kepengarangannya. Oka Rusmini telah menerbitkan 12 buku dan dalam karyakaryanya, ia membahas tentang kehidupan perempuan Bali. Beberapa karyanya yang telah terbit diantaranya berbentuk novel yaitu berjudul Tarian Bumi (2000), Kenanga (2003), Tempurung (2010), kumpulan puisi berjudul Monolog Pohon (1997) dan Patiwangi (2003), serta kumpulan cerpen berjudul Sagra (2017).

Penelitian ini dilakukan untuk melihat lokalitas perempuan Bali yang dapat dilihat melalui representasi identitas mereka yangdipengaruhi oleh agama, adat dan kuasa patriarki. Oleh karena ini analisis dilakukan berlandasan dengan teori literasi budaya untuk memahami suatu budaya melalui teks, teori femininitas normatif yang menunjukkan bagaimana perempuan terikat dengan nilai dan sikap feminin, serta teori lokalitas sebagi ruang kultural yang menyimpan potret sosial.

\section{LANDASAN TEORI}

Pada karya-karyanya, Oka Rusmini menyampaikan tentang kehidupan perempuan Bali yang didominasi oleh kuasa patriarki. Ia menuliskan bagaimana perempuanperempuan Bali harus bekerja keras untuk menghidupi dan mengusahakan yang terbaik untuk keluarganya, khususnya mereka yang dari kasta Sudra. Meskipun begitu, tidak berarti perempuan dari kasta Brahmana tidak memiliki masalah dalam kehidupan yang sama rumitnya, karena mereka diwajibkan untuk menjaga kebangsawanan dirinya dan keluarganya. Sedangkan laki-laki dalam karyanya diceritakan hanya memikirkan tentang tubuh perempuan secara seksual, dilayani, menghamburkan harta, dan bersantai, sangat bertolak belakang dengan tokoh perempuannya yang terus bekerja dengan keras. Dalam karyanya juga, kasta tokoh-tokoh yang sering dimunculkah ialah kasta Brahmana dan Sudra, karena dari kedua kasta tersebut masalah yang terkait pada perempuan sering muncul.

Budaya yang melingkup hidup perempuan merupakan lokalitas yang membentuk identitas perempuan. Lokalitas menurut Mahayana (2009) merupakan ruang kultural yang menyimpan sebuah potret sosial, bahkan juga ideologi yang direpresentasikan melalui tokoh-tokohnya dan dinamika kultural yang mengungkapkan dan menyimpan nilai-nilai tentangmanusia dalam kehidupan berkebudayaan. Lokalitas perempuan Bali dalam cerpen dipengaruhi oleh representasi identitas perempuan Bali dan hal-hal yang mempengaruhi identitas tersebut, yaitu agama, adat dan budaya patriarki. Mantra (2011) menyampaikan perempuan Bali disimbolkan sebagai pradana atau femininitas. Oleh karenanya lokali- 
tas perempuan Bali sangat terkait dengan femininitas normatif yang telah terbentuk pada budayanya.

Pada dasarnya perempuan sering disosialisasikan dengan nilai dan sikap feminin yang diasosiasikan dengan pasif, submisif dan ketergantungan (Hollows, 1999).Young (1980:137--156) menyampaikan femininitas sebagai suatu struktur dan kondisi yang membatasi perempuan pada suatu masyarakat untuk melakukan sesuatu. Menurut Mead melalui Klein (1950:3--12), sejak kelahirannya, laki-laki dianjurkan untuk berusaha agar menjadi lebih baik, sedangkan perempuan dianjurkan untuk dengan santai menerima dirinya apa adanya.

Penelitan terhadap karya-karya Oka Rusmini telah dilakukan, salah satunya adalah mengenai identitas perempuan Bali dalam kumpulan puisi Warna Kita yang ditulis oleh Sandi (2013). Hasil penelitiannya mengungkapkan bahwa identitas berhubungan dengan ciri atau jatidiri, tentang identitas perempuan Bali dalam kumpulan puisi Warna Kita yang dipahami dengan tiga pilar yaitu konstruksi femininitas, peran gender, dan relasi gender yang kemudian menunjukkan bahwa perempuan Bali masih dianggap sebagai warga kelas dua. Hasil selanjutnya menunjukkan tentang penanaman ideologi feminisme liberal serta pembangunan puisi dengan sarana retorika dan citraan yang dilakukan Oka Rusmini dalam kumpulan puisi Warna Kita untuk memperkuat perlawanan yang dilakukannya terhadap budaya patriarki di Bali. Kemudian penelitian yang dilakukan oleh Richardo dan Martono (2014) tentang unsur retorika pada novel Tarian Bumi karya Oka Rusmini. Hasil penelitian menunjukkan yang dominan digunakan dalam novel yaitu majas hiperbola, penyiasatan struktur metafora, dan citraan penglihatan. Menurutnya hal ini dilakukan dengan alasan untuk menunjukkan karakter tulisan dan memper- kuat kritik yang ingin disampaikan oleh Oka Rusmini. Penelitian lainnya yaitu tentang "Subjektifitas Perempuan dalam Cerpen Cendana Karya Oka Rusmini" yang dilakukan oleh Rojak, Rahayu, dan Priyatna (2017) menununjukan bahwa menunjukan bahwa karakter protagonis perempuan ditampilkan sebagai subjektivitas yang memainkan tubuh sebagai bagian penting dalam relasinya dengan tokoh laki-laki dalam kerangka heteroseksualitas. Ketiga penelitian tersebut menunjukkan bahwa Oka Rusmini berusaha melakukan perlawanan terhadap adatnya terutama yang mendiskriminasi perempuan melalui karyakaryanya.

\section{METODE PENELITIAN}

Objek penelitian yang digunakan adalah kumpulan cerpen berjudul Sagra karya Oka Rusmini. Dari kumpulan cerpen tersebut dipilih tiga cerpen yaitu Sepotong Kaki, Sagra dan Cenana. Pemilihan ketiga cerpen tersebut berdasarkan pembatasan ruang lingkup pada penelitian ini yaitu cerpen dengan tokoh utama perempuan. Tokoh utama perempuan menjadi kekuatan pada penelitian ini untuk melihat lokalitas perempuan dengan latar budaya Bali.

Langkah-langkah penelitian ini adalah sebagai berikut. Pertama, penentuan dan klasifikasi data, yaitu mengumpulkan data sesuai dengan rumusan masalah tentang sistem kasta yang membentuk identitas dan lokalitas perempuan di Bali, lalu pengaruh agama Hindu, adat dan kuasa patriarki yang masih kental memengaruhi lokalitas perempuan Bali. Data primer berupa tiga judul cerpen yang telah disebutkan di atas. Data sekunder berupa referensi yang terkait dengan lokalitas perempuan Bali.

Kedua, analisis data yaitu aplikasi teori femininitas normatif pada kumpulan cerpen Sagra. Data yang sudah terkumpul dikelompokkan sesuai teori yang telah ditentukan 
dan referensi digunakan untuk melihat lokalitas perempuan. Analisis dilakukan dengan mengambil beberapa kutipan cerpen yang mewakili rumusan masalah. Metode yang digunakan adalah kajian pustaka dengan teknik analisi isi (content analysis). Metode kajian pustaka dilakukan dengan cara membaca, menandai dan menganalisis teks-teks dalam cerpen yang menunjukan lokalitas perempuan yang berlatar budaya Bali.

\section{HASIL DAN PEMBAHASAN}

Dalam cerita pendek"Sepotong Kaki", "Sagra" dan "Cenana" maka dapat dilihat dua hal berikut: Representasi identitas perempuan Bali dan pengaruh agama, adat dan kuasa patriarki terhadap identitas perempuan Bali sebagai bentuk lokalitas perempuan Bali.

\section{Representasi identitas perempuan Bali}

Dari ketiga cerpen tersebut terdapat beberapa identitas yang dominan pada perempuan Bali. Antara lain:

\section{Sistem Kasta}

Sistem kasta memiliki peran yang sangat penting dalam masyarakat Bali. Anwar (2016:1-11) menyampaikan kasta sebagai kedudukan atau penggolongan masyarakat berdasarkan pada keturunan, kasta masyarakat Bali terbagi atas empat kasta yakni Brahmana berkaitan dengan kependetaaan dan memiliki kedudukan tertinggi dalam struktur kasta; Ksatria merujuk pada mereka yang berprofesi sebagai abdi negara atau kerajaan dan para keturunan raja; Waisya identik dengan mereka yang bergelut di bidang perdagangan; dan Sudra adalah para buruh atau petani, tak bergelar dan merupakan kasta terendah. Keempat kasta tersebut memengaruhi berbagai aspek kehidupan masyarakat Bali diantaranya identitas, hak, peran dan relasi.
Hal yang paling terlihat pada pembagian kasta tersebut adalah nama dan panggilan yang disandingkan pada pemilik kasta. Dengan melihat keduanya seseorang, kita dapat melihat tidak hanya kastanya, tetapi juga status sosial orang tua atau keturunannya.

Dalam salah satu kutipan cerpen berjudul "Sepotong Kaki" terlihat bagaimana sistem kasta mendiskriminasi perempuan. Seorang tokoh perempuan bernama Centaga tidak berhak memanggil Ibunya dengan sebutan Ibu karena perbedaan kasta di antara mereka. Centaga anak dari laki-laki Brahmana yang menikah dengan perempuan Sudra. Meskipun Centaga menjadi Brahmana ketika dilahirkan, namun Ibunya tetap kasta Sudra. Ibunya lebih rendah dari Centaga dan ia kehilangan haknya sebagai seorang Ibu bagi Centaga. Hal itu dapat dilihat dari cara Centaga memanggilnya, seperti dalam kutipan di bawah ini.

"Perempuan aneh itu kupanggil 'meme'. Aku tak boleh memanggilnya

'ibu', karena perempuan yang me-

lahirkanku itu bukan seorang perem-

puan brahmana." (Rusmini, 2001:43)

Selain itu pada cerpen berjudul "Cenana" juga terlihat sistem kasta yang memposisikan perempuan secara diskriminatif. Luh Sapti adalah seorang berkasta sudra yang menikah dengan laki-laki Brahmana, saat menikah ia sudah hamil lima bulan. Ketika anaknya, Cenana, lahir dan seharusnya memiliki kasta Brahmana karena ayahnya, ia kehilangan haknya sebagai perempuan Brahmana. Cenana tak berhak menggunakan nama Ida Ayu, selayaknya seorang perempuan brahmana karena ibunya telah hamil sebelum pernikahan terjadi. Apabila ia memiliki seorang adik, ia harus patuh dan taat pada adiknya. Dalam cerita, Cenana bersyukur ibunya tidak memiliki anak lagi setelah dirinya karena 
ia tidak mau jika harus menghormati anak yang lebih kecil darinya. Berikut kutipan yang menunjukkan diskriminasi yang terjadi pada Luh Sapti dan Cenana yang kehilangan hak-haknya sebagai seorang Brahmana.

"Ibuku seorang perempuan sudra, Luh Sapti namanya. Karena dia menikah dengan Ida Bagus Dawer, dia bergelar Jero Sandat katika kawin dengan bapakku, Jero Sandat telah hamil 5 bulan dan baru dikawini. Karena itu orang-orang desa tidak mengakui Cenana sebagai Ida Ayu. Dia memang boleh tetap tinggal di Griya, tempat keluarga besarnya yang keluarga brahmana. Tapi, haknya sebagai keluarga dicabut." (Rusmini, 2001:184)

2. Kasta Menentukan Identitas dan Peran Perempuan Bali

Di Bali nama menjadi identitas seorang perempuan. Identitas ini dapat berubahubah tergantung posisi sosialnya saat ia lahir hingga ia menikah. Dalam sistem kasta, pemberian nama pada seseorang dipengaruhi oleh kasta yang dimilikinya saat lahir ke dunia. Seperti dalam kutipan cerpen "Sepotong Kaki". Centaga tidak diberi nama Ida Ayu, hanya menggunakan Ida tanpa Ayu. Hal ini dipengaruhi oleh statusnya, yang lahir dari ayah Brahmana dan ibu yang berkasta Sudra.

“...Beri dia nama Ida Putu Centaga Nareswari, karena ibunya bukan seorang Ida Ayu." (Rusmini, 2001:43)

Selain identitas, kasta juga memengaruhi peran seseorang. Seorang Brahmana memiliki peran yang berbeda dengan kasta lain. Bahkan dalam peran itu, terdapat peran yang terhormat dan sebaliknya. Salah satunya dalam cerpen "Sagra". Sagra yang dibesarkan dengan kasta Sudra dan bekerja di griya untuk mengasuh anak majikannya yang seorang Brahmana harus menjalankan perannya sebagai seorang Sudra. Meskipun Sagra bekerja di griya, ia tetaplah seorang Sudra yang lebih rendah dari Brahmana dan dianggap dapat menodai kebangsawanan seseorang hanya dengan kehadirannya. Dalam cerpen ia diharuskan menjaga kebangsawan anak majikannya yang berkasta Brahmana sebaik-baiknya. Sebagai pengasuh, ia bahkan tidak boleh makan satu piring dengan anak asuhnya. Hal ini dapat terlihat pada kutipan berikut.
“Kupilih kau untuk menjaganya, Sagra. Kau harus jaga kebangsawan- annya. Jangan pernah makan satu piring dengannya. Jaga dia sebagai bangsawan. Jangan kotori darah biru- nya. Kau paham?!" (Rusmini, 2001:95)

3. Perempuan Bali Harus Mematuhi Femininitas Normatifnya

Femininitas normatif berhubungan dengan bagaimana seorang perempuan bersikap dan berpenampilan dalam budaya tertentu. Dalam kutipan cerpen "Sepotong Kaki", ketika Centaga ingin menari untuk sebuah upacara, ia tidak diberi kesempatan karena tidak memiliki kaki yang sempurna untuk menari. Femininitas normatif di sini menunjukan bahwa seorang perempuan Bali seharusnya memiliki fisik sempurna untuk melakukan tarian dalam upacara. Tanpa fisik yang sempurna, seorang perempuan Bali yang ingin menari dianggap menodai kesucian upacara tersebut. Seperti terlihat dalam kutipan berikut.

“...Penari-penarinya harus sempurna.

Harus memiliki kaki yang lengkap.

Jangan merusak upacara ini, Cen-

taga,..." (Rusmini, 2001:50)

Selain itu, dalam cerpen "Cenana", femininitas normatif lainnya yang tampak yaitu seorang perempuan Bali seharusnya 
menjalankan perannya sesuai kasta masingmasing. Seorang Brahmana harus menjaga kastanya agar tetap mulia. Ia tidak diperbolehkan melakukan hal-hal yang secara adat tidak boleh dilakukan. Dalam kutipan berikut, Siwi seorang perempuan Brahmana yang tidak dikarunia anak mengangkat anak dari kasta Sudra. Namun hal ini menuai reaksi keras dari keluarga besarnya, karena menurut aturan seorang Brahmana harus memiliki darah Brahmana sejak lahir, sedangkan anak yang akan diangkatnya merupakan seorang anak dari laki-laki dan perempuan sudra.

"Kau tidak mengerti menjadi wanita brahmana. (Rusmini, 2001:175)

"Kau rusak tatanan kebangsawan yang telah kita bangun!" (Rusmini, 2001:176)

4. Tubuh Merupakan Bagian Identitas Perempuan Bali

Melalui cerpen ini, identitas perempuan Bali dapat dilihat tidak hanya dari nama dan panggilan seseorang, citra tubuh juga menjadi identitas seorang perempuan Bali. Kasta digambarkan dapat dilihat dari perbedaan tubuh perempuan Brahmana dan Sudra. Perempuan Brahmana digambarkan begitu cantik sedangkan perempuan Sudra sangat kasar dan buruk. Hal ini digambarkan seperti kutipan berikut.

"Mertuaku itu, perempuan bangsawan. Aku percaya kemurnian karatnya. Dia memiliki mata yang besar, wajah yang runcing, tubuh yang ramping. Rambutnya tebal, hitam, dan panjang sepantat..." (Rusmini, 2001:166)

Siwi, mertua Cenana, seorang perempuan Brahmana yang digambarkan memiliki fisik sempurna. Ia memiliki mata yang besar, wajah yang runcing, tubuh yang ramping, rambut yang tebal, hitam dan panjang sepantat. Deskripsi perempuan yang cantik dan ideal di Bali. Berbeda dengan deskripsi perempuan Sudra dalam cerpen tersebut yang digambarkan sebaliknya. Sebagai perempuanSudra yang identik dengan buruh dan petani, mereka digambarkan memiliki kehidupan yang berat untuk bertahan hidup. Oleh karena itu tubuhnya digambarkan tak terawat dan sakit-sakitan. Dalam cerpen tersebut, penggambaran kedua perbandingan itu adalah antara perempuan Brahmana dan Sudra dengan usia yang dekat.

"Kulitku terawat, sedangkan kulit perempuan di depanku seperti kulit sawo busuk, keriput. Tak ada kemudaan dan keindahan. Rambutnya tinggal satu-dua jumput, malah hampir botak. Dadanya begitu tipis, bahkan tulang-tulang dadanya terlihat ketika kebayanya kusam dan bau tersingkap." (Rusmini, 2001:172)

\section{Agama, Adat dan Kuasa Patriarki yang Memengaruhi Identitas Perem- puan Bali sebagai Bentuk Lokalitas}

Setelah membahas mengenai representasi identitas perempuan Bali dalam cerpen berjudul "Sagra" terdapat juga hal-hal yang mempengaruhi identitas tersebut. Dalam pembacaan pada cerpen didapatkan agama, adat, dan kuasa patriarki memiliki pengaruh besar terhadap identitas Bali tersebut. Pengaruh tersebut membentuk lokalitas perempuan Bali, karena keterkaitannya terhadap budaya-budaya yang ada di Bali.

a. Agama

Dalam ajaran agama Hindu terdapat pengelompokan anggota masyarakat yang disebut catur warna dan catur wangsa. Catur warna yaitu pengelompokan anggota masyarakat menjadi empat kelompok berdasarkan kewajiban, bakat, atau jenis pe- 
kerjaan. Sedangkan catur wangsa berarti pengelompokan masyarakat menjadi empat berdasarkan keturunannya. Hardy, Setiawan, \& Prayitno (2016) menyampaikan dalam perkembangan agama Hindu di Bali, keduanya cenderung disamakan dan catur wangsa disalahartikan menjadi kasta yang terkait dengan keturunan atau ras.

Pada agama Hindu di Bali, terdapat aturan yang melarang seorang brahmana untuk beribadah di pura desa karena dianggap akan menodai kesucian darah mereka, oleh karena itu setiap keluarga Brahmana memiliki pura di rumah mereka masing-masing yang disebut pura griya. Sedangkan seseorang dengan kasta Sudra hanya diperbolehkan beribadah di pura desa. Hal ini salah satunya dapat dilihat dalam cerpen "Sagra".

"Mereka memang tidak pernah sembahyang ke Pura desa. Karena mereka sebagai kasta tertinggi dalam struktur masyarakat Bali, bersembahyang di Pura desa milik masyarakat desa tak ubahnya mencemarkan kebangsawanan." (Rusmini, 2001:91)

b. Adat Mengatur dan Mempengaruhi Hidup perempuan Bali

Adat berarti tata cara kehidupan. Perempuan adalah orang-orang yang diberikan tugas untuk menjaga adat, oleh karenanya di Bali adat memiliki pengaruh besar terhadap kehidupan perempuan-perempuannya. Dari kasta manapun, ketika seorang perempuan yang menyalahi aturan adatnya maka ia akan dianggap sebagai perusak tatanan keluarganya. Pada kasta Brahmana khususnya, keturunannya wajib mentaati apa yang telah dijalani atau dititipkan oleh lelehur mereka. Ketika dilanggar maka semua orang akan menganggap bahwa ia sudah tak memiliki keyakinan pada adatnya itu.
"Orang hidup itu memiliki aturan, Siwi. Leluhur keluarga besar kita sudah menanamkannya untuk kita? Apa yang kau perbuat kepada mereka?!" (Rusmini, 2001:176)

Kutipan tersebut menceritakan tentang Siwi, seorang perempuan Brahmana yang tidak dapat memiliki anak dan ingin mengangkat anak dari seorang perempuan Sudra. Orang-orang di sekitarnya telah menyarankan Siwi untuk mengambil anak dari salah seorang saudaranya yang jelas dari kasta Brahmana, atau tidur dengan salah satu dari mereka agar mendapatkan seorang anak Brahmana, tetapi ia menolaknya dan justru memilih anak dari kasta Sudra.

Selain menyalahi aturan dalam mengangkat anak Sudra, ia juga telah menyalahi femininitas normatif perempuan Bali, yaitu tidak dapat melahirkan seorang anak. Perbuatan ini membuat orang-orang menganggapnya sebagai perempuan Brahmana yang tidak beradat.

Kemudian secara adat seorang Brahmana harus dilayani oleh kasta Sudra. Jika seorang Brahmana memiliki keperluan dengan seorang Sudra, maka seseorang dari kasta Sudra yang seharusnya menghadap ke tempat tinggal Brahmana. Hal ini dapat dilihat pada kutipan berikut.

“Hyang Jagat! Harusnya tiang yang
datang ke tempat Ratu bukan Ratu
yang datang ke gubuk tiang. Harus-
nya Ratu tidak datang sendiri Ratu
bisa memerintah Wang Jero. Kalau
Ratu berkenan tiang pasti akan da-
tang." (Rusmini,2001:169--170)

c. Kuasa Patriarki: Perempuan Bali pada Akhirnya Berada di bawah Kuasa LakiLaki

Kuasa patriaki berhubungan dengan relasi antara perempuan dan laki-laki. Walby melalui Setiawan (2016) mendefi- 
nisikan patriarki sebagai sistem struktur sosial dan praktik di mana laki-laki mendominasi, menekan dan mengeksploitasi perempuan. Dalam kuasa patriarki laki-laki lebih dianggap memiliki kuasa lebih tinggi daripada perempuan.

Sistem kekeluargaan di Bali sangatlah patriarkal. Keturunan seseorang akan mengikuti leluhur laki-laki. Ketika seorang perempuan tidak dapat melahirkan anak laki-laki, ia dianggap perempuan tidak sempurna dan ditekan oleh keluarganya untuk mendapatkan anak laki-laki salah satunya dengan cara memaksa anak perempuannya menikah dengan laki-laki yang sederajat. Penekanan ini biasanya dilakukan pada anak-anak perempuan sejak mereka masih kecil. Berikut kuasa patriarkal yang tampak dalam cerpen "Cenana".

“Kepercayaan mereka hanya menguntungkan pihak laki-laki. Seorang lelaki mengawini perempuan dan leluhur yang menitis di roh anaknya adalah leluhur dari pihak laki-laki." (Rusmini, 2001:117)

Perempuan Bali khususnya yang memiliki kasta sudra digambarkan memiliki peran ganda dalam kehidupan keluarganya. Selain harus mengurus suami dan anak-anaknya, mereka juga harus bekerja di luar untuk memenuhi kebutuhan hidup mereka. Tanpa perempuan Bali, roda kehidupan di Bali mungkin tidak akan berjalan dengan baik, karena pekerjaan sebagian besar dilakukan oleh seorang perempuan.

Dalam cerpen "Sepotong Kaki" dan "Cenana", laki-laki digambarkan tidak bekerja, tetapi istrinya tetap harus bertugas untuk melayani keperluannya. Seperti pada kutipan di bawah ini. Dawer seorang lakilaki Brahmana, ia diceritakan tidak memiliki pekerjaan dan hanya mengadu ayam setiap harinya. Hidupnya di topang oleh meng- andalkan hasil kerja istri-istrinya. Uang miliknya lebih banyak digunakan untuk memenuhi kebutuhan hidupnya sendiri.

“Di sini setiap perempuan adalah lelaki. Bekerja adalah sembahyang dan menari." (Rusmini, 2001:47)

“Padahal, Dawer tidak bekerja. Lelaki itu selalu bangun siang hari. Nasi, kopi, dan lauk harus tersedia ketika lelaki itu bangun." (Rusmini, 2001: 185)

\section{PENUTUP}

Berdasarkan pada pembacaan cerpencerpen tersebut, perempuan Bali direpresentasikan melalui sistem kasta, identitas dan peran, femininitas normatif, dan tubuh sebagai identitas. Dalam cerpen digambarkan bahwa identitas untuk perempuan Bali menjadi suatu hal yang sangat penting untuk kelangsungan hidup mereka. Tanpa identitas yang jelas hak-hak yang mereka miliki bisa jadi hilang atau dicabut dan akan berpengaruh pada keturunan-keturunannya, terutama ketika keturunannya adalah seorang anak perempuan. Oleh karena itu, banyak diceritakan usaha perempuan Bali untuk mendapatakan pasangan dengan kasta yang lebih tinggi untuk memperbaiki kelangsungan hidup keturunannya, meskipun ia tetap akan dianggap rendah oleh keluarga suaminya. Selain itu juga untuk mengangkat derajat sosialnya dalam kehidupan.

Identitas tersebut tentunya sangat dipengaruhi oleh agama, adat dan kuasa patriarki yang juga mempengaruhi lokalitas perempuan Bali. Agama memiliki peran dalam memunculkan pengelompokan masyarakat di Bali, yaitu kasta. Kasta juga merupakan bagian dari adat Bali yang harus dipatuhi, dan ketika dilanggar maka para pelakunya akan mendapatkan sanksi-sanksi 
sosial. Adat menjadi salah satu hal yang membentuk femininitas normatif perempuan Bali yang mengharuskan mereka untuk pasif menerima nasib dan harus mematuhinya. Bahkan ketika tubuh mereka tidak mampu untuk mengikuti adat, maka mereka dianggap sebagai perempuan yang tidak sempurna. Hal ini juga terkait dengan kuasa patriarki yang memposisikan perempuan di bawah laki-laki dalam berbagai hal.

Melalui karya-karyanya, Oka Rusmini membagi pengalamannya berperan sebagai seorang perempuan Bali. Dengan keras ia menampilkan tekanan batin yang dirasakan perempuan Bali dan diskriminasi atau ganjaran yang didapatkan ketika mereka melawan lokalitasnya. Tulisan Oka Rusmini yang konsisten membicarakan tentang kehidupan perempuan Bali menunjukkan usahanya untuk melakukan perlawanan terhadap diskriminasi yang terjadi pada perempuan Bali melalui media yang diterima oleh pembaca secara luas dan dapat menyampaikan isu-isu suatu kebudayaan yaitu karya sastra. Memahami teks sastra karya Oka Rusmini terutama bahasan dalam makalah ini merupakan salah satu upaya literasi untuk mendapatkan pemahaman tentang budaya dan lokalitas perempuan Bali

\section{DAFTAR PUSTAKA}

Abdulfatah, M. R., Widodo, S. T., \& Rohmadi, M. 2018. Pendidikan Karakter dalam Novel Mahamimpi Anak Negeri Karya Suyatna Pamungkas Tinjauan Psikologi Sastra. Jurnal Gramatika, 4, 1223.

Anwar. 2016. 'Ini Kan Bukan Bali': Interaksi Antar-Kasta Masyarakat Transmigran di Desa Kertoraharjo, Kabupaten Luwu Timur, Sulawesi Selatan. Jurnal Etnosia, 1(2), 1-11.

Astuti, T., \& Umiati. 2018. Nilai Budaya dan Feminisme dalam Kumpulan Cerpen
Jeramba-Jeramba Malam: 10 Cerpen Terbaik Sayembara Menulis Cerpen Lokalitas Lubuklinggau Karya Mimi La Rose, dkk. Silampari Bisa, 1(1), 98-115.

Hardy, I. G. N. W., Setiawan, B., \& Prayitno, B. 2016. Pengaruh Sistem Catur Wangsa terhadap Perwujudan Tata Spasial Kota Peninggalan Kerajaan Hindu di Bali: Kasus Kota Karangasem. Jurnal Kajian Bali, 6(2), 79-96.

Hirsch, E. D. 1983. Cultural Literacy. The American Scholar, 52(2), 159-169.

Hollows, J. 1999. Feminism, Femininity, and Popular Culture. Manchester: Manchester University Press.

Kemendikbud. 2017. Materi Pendukung Literasi Budaya dan Kewargaan. Jakarta: Kemendikbud.

Klein, V. 1950. The Stereotype of Femininity. Journal of Social Issues, 6(3), 3-12.

Mahayana, M. S. 2009. Lokalitas dalam Sastra Indonesia. Horison.

Mantra, G. 2011. Kekerasan Ideologi Patriarki pada Perempuan Bali. Retrieved from http:// www.balisruti.com/kekerasan-ideologipatriarki-pada-perempuan-bali.html.

Noor, A. 2015. Lokalitas dan Metropolitas. Human Studies, 3, 137-156. dalam Sastra Kita. Retrieved from https:// agusnoorfiles.wordpress.com/2015/01/26/ lokalitas-dan-metropolitas-dalam-sastra-kita/

Rojak, M. A., Rahayu, L. M., \& Priyatna, A. 2017. Subjektivitas Perempuan dalam Cerpen “Cenana”Karya Oka Rusmini Jurnal Pesona, 3(2), 100-114.

Richardo, A. A., Syam, C., \& Martono. 2014. Unsur Retorika dalam Novel Tarian Bumi Karya Oka Rusmini. Jurnal Pendidikan Dan Pembelajaran, 3(10).

Saepudin, E., Damayani, N. A., \& Rusmana, A. 2018. Model Literasi Budaya Masyarakat Tatar Karang di Kecamatan Cipatujah Kabupaten Tasikmalaya. 
Berkala Ilmu Perpustakaan Dan Informasi, 14(1).

Sandi. 2013. Identitas Perempuan Bali dalam Kumpulan Puisi Warna Kita Karya Oka Rusmini (Analisis Kritik Sastra Feminis). Yogyakarta: Universitas Negeri Yogyakarta.

Setiawan, I. 2016. PATRIARKI: Masyarakat, budaya, dan negara dalam kuasa lelaki. Retrieved from http://matatimoer.or.id/ 2016/04/05/patriarki-masyarakat-budayadan-negara-dalam-kuasa-lelaki/
Windiyarti, D. 2008. Pemberontakan Perempuan Bali Terhadap Diskriminasi Kelas dan Gender: Kajian Feminis Novel Tarian Bumi Karya Oka Rusmini. Humaniora, 20(3), 286-294.

Young, I. M. 1980. Throwing like a Girl: A Phenomenology of Feminine Body Comportment Motility and Spatiality. 